\title{
Original bundle-based management of septic shock in nagoya university emergency icu
}

\author{
N Matsuda*, S Matsushima, H Umino, T Higashi, G Makishi, T Yoshida, Y Shioya, A Numaguchi \\ From ESICM LIVES 2015 \\ Berlin, Germany. 3-7 October 2015
}

\section{Intr}

Nagoya University Hospital set up an original management bundle for septic shock on 1st May 2011. This study was intended to verify the strategy.

\section{Methods}

This study adopted retrospective analysis. As the basis for management of septic shock, 13 main elements were combined as the management bundle of septic shock, which contained antibiotics followed culture sampling, standard precaution, infusion therapy adjusted with echocardiogram, early goal-directed original infusion methods, lactate clearance, open lung strategy, analgesia and sedation, $\beta$-adrenergic receptor non-stimulation, urine volume management, continuous henofiltration, early enteral nutrition within 48 hours, and early rehabilitation within three days. We analyzed the feasibility and the outcome for septic shock in accordance with this policy from 1st May 2011 to 31st December 2014 as compared with in-ICU mortality rate of more than $25 \%$ in 2010.

\section{Results}

Out of total 1,714 cases managed in our ICU among the period, 96 were included with septic shock. The sex ratio was 63:33, mean age was $64.6 \pm 18.7$ years old, mean ICU stay was $11.6 \pm 13.4$ days and APACHE II score was $28.6 \pm 7.8$. The shock withdrawal rate was $99.0 \%$, and inICU mortality and 28 day mortality was $5.2 \%(\mathrm{n}=5)$ and $6.3 \%(\mathrm{n}=6)$, respectively. The dominant causes of death were DNR order with intra-abdominal infection, intestinal necrosis and soft tissue infection.

Nagoya University Graduate School of Medicine, Emergency \& Critical Care Medicine, Nagoya, Japan

(c) 2015 Matsuda et al.; This is an Open Access article distributed under the terms of the Creative Commons Attribution License (http:// creativecommons.org/licenses/by/4.0), which permits unrestricted use, distribution, and reproduction in any medium, provided the original work is properly cited.

\section{Conclusions}

A high survival rate was obtained with our septic shock management bundle as compared to our management in 2010 and sepsis registry in the Japanese Society of Intensive Care Medicine.

\section{Grant Acknowledgment}

Grants-in-Aid for Scientific Research in Japan.

Published: 1 October 2015

doi:10.1186/2197-425X-3-S1-A228

Cite this article as: Matsuda et al:: Original bundle-based management

of septic shock in nagoya university emergency icu. Intensive Care

Medicine Experimental 2015 3(Suppl 1):A228.

\section{journal and benefit from:}

- Convenient online submission

- Rigorous peer review

- Immediate publication on acceptance

- Open access: articles freely available online

- High visibility within the field

- Retaining the copyright to your article

Submit your next manuscript at $>$ springeropen.com 